\title{
Cold hardiness of Neoseiulus californicus and $N$. womersleyi (Acari: Phytoseiidae)
}

\author{
Tetsuo GotoH $^{1 *}$, Takashi AKIZAWA ${ }^{1}$, Masahiko WAtanabe ${ }^{2}$, Akiko TsuChIYA $^{1}$ \\ and Sayaka SHIMAZAKI ${ }^{1}$ \\ ${ }^{1}$ Laboratory of Applied Entomology and Zoology, Faculty of Agriculture, Ibaraki University, Ami, \\ Ibaraki 300-0393, Japan \\ ${ }^{2}$ National Institute of Agrobiological Sciences, Tsukuba, Ibaraki 305-8634, Japan
}

(Received 9 September 2005; Accepted 24 October 2005)

\begin{abstract}
Mites of the genus Neoseiulus are predatory mites that feed on pest species such as the two-spotted spider mite (Tetranychus urticae) and therefore act as biocontrol agents. Since the 1990s, the population of $N$. californicus in central and southwestern Japan has increased sharply, replacing the native $N$. womersleyi in many orchards in this area. However, in orchards of northern Japan, $N$. californicus is much less abundant than $N$. womersleyi. Here we tested the hypothesis that the lower abundance of $N$. californicus in the north is due to a lack of cold hardiness. The mean supercooling points of adult females of two strains of $N$. californicus (an indigenous strain and a commercial strain, neither of which enters diapause) and diapause and non-diapause $N$. womersleyi were all in the range $-21.9 \sim-23.3^{\circ} \mathrm{C}$ and were not significantly different. However, more than $50 \%$ of diapause females of $N$. womersleyi survived for more than 7 days exposed to $-5^{\circ} \mathrm{C}$, while most females of the non-diapause $N$. womersleyi and the two $N$. californicus strains died after $3-5$ days of exposure to $-5^{\circ} \mathrm{C}$. Exposure of adult females to $-5^{\circ} \mathrm{C}$ for various periods did not significantly affect subsequent fecundity and egg viability. These results suggest that the lower cold hardiness of $N$. californicus might be one of the factors halting its northern advance, but it is probably not sufficient to be the only factor.
\end{abstract}

Key words: Neoseiulus californicus, Neoseiulus womersleyi, cold hardiness, supercooling point, diapause

\section{INTRODUCTION}

Predatory mites have been the focus of many studies because of their importance as predators of phytophagous mites and small arthropod pests (reviewed by Sabelis, 1985). The predatory mite Neoseiulus californicus (McGregor) is found on various crops and deciduous trees in Europe, North and South America and Asia (Schausberger and Croft, 2000). In Japan, this species was first collected in 1963 (Ehara, 1964), but no further collections were made until the 1980s (Amano et al., 2004). At present, the indigenous $N$. californicus strain is abundant and found on various deciduous trees and weeds. $N$. californicus is classified as a generalist predator because it feeds on spider mites, tarsonemid mites, other small arthropods and pollen (Castagnoli et al., 1999). A commercial strain of $N$.

* Corresponding author: e-mail: gotoh@mx.ibaraki.ac.jp; Tel/Fax: +81-29-888-8560 DOI: 10.2300/acari. 14. 93 
californicus $\left(\right.$ Spical $^{\circledR}$ ) has also been used in many countries as a biocontrol agent, and has been used in greenhouses and fields in Japan since 2003. On the other hand, $N$. womersleyi (Schicha) is classified as a specialist predator because it feeds exclusively on spider mites (Schausberger and Croft, 2000). N. womersleyi is considered to be an effective natural enemy of spider mites on deciduous fruit crops in Asia, Australia and New Zealand (Ehara et al., 1994; Hamamura, 1982).

$N$. womersleyi used to occupy a dominant position among phytoseiid fauna in Japanese pear orchards throughout Japan, where pests were largely managed with chemicals. Since the 1990s, the population of the predatory mite N. californicus in central and southwestern Japan has increased sharply. In many orchards in this area, N. californicus has largely replaced $N$. womersleyi (Amano et al., 2004). However, in orchards of northern Japan, the population of $N$. californicus has hardly increased (Amano et al., 2004). Why N. californicus replaced $N$. womersleyi in the south but not in the north has been the subject of much speculation among Japanese acarologists. Possible factors affecting the distributions of these species include cold hardiness, intra-guild predation, interspecific competition for limited resources, and susceptibility to acaricides that became available in the 1990s. However, Amano et al. (2004) argue that differential susceptibility to acaricides alone cannot account for the difference in distributions of these two species.

Adult females of $N$. womersleyi obtained in many areas in Japan enter a reproductive diapause in preparation for winter (Hamamura, 1982; Kishimoto and Takafuji, 1994). On the other hand, the diapause propensity of $N$. californicus varies among strains, ranging from $0 \%$ to $100 \%$ (Castagnoli et al., 1996; Hart et al., 2002; Jolly, 2000). To our knowledge, however, there are no available data on diapause ability in either the indigenous strain of $N$. californicus or the Spical strain that is used in Japan.

Overwintering terrestrial arthropods are generally considered to have two different strategies for survival at low temperatures: freeze tolerance and freeze intolerance or avoidance (Lee, 1991; Salt, 1961). Most insects and all mite species studied are freeze intolerant (Broufas and Koveos, 2001b) and cannot survive ice formation within their tissues (Morewood, 1992; Sømme, 1982). The supercooling point (SCP), the temperature at which spontaneous tissue freezing occurs, represents the absolute lower lethal temperature for freeze-intolerant species (Lee, 1991). However, many freeze-intolerant species often die at temperatures above the SCP as a result of chilling injury or cold shock (Lee and Denlinger, 1985; Lee, 1991).

In the present study, to discuss possible reasons for the lack of advancement of $N$. californicus to the north, we examined certain basic cold hardiness parameters of the indigenous and alien strains of $N$. californicus and the indigenous strain of $N$. womersleyi. We examined the diapause propensity of the two $N$. californicus strains, the SCPs and cold hardiness at $-5^{\circ} \mathrm{C}$ (a temperature well above the SCP).

\section{MATERIALS AND METHODS}

Mites. Two N. californicus strains and a N. womersleyi strain were used in this study. One was the indigenous $N$. californicus strain established with mites collected from a pear 
orchard in Ichihara $\left(35^{\circ} 28^{\prime} \mathrm{N}-140^{\circ} 04^{\prime} \mathrm{E}\right)$, Chiba Pref., in the central part of Japan, on 17 August 1995 (Amano et al., 2004). Another was the alien N. californicus strain, Spical ${ }^{\circledR}$, which was provided by Arysta LifeScience Co., Ltd., in July 2001, but no information was available on the origin of the strain. The $N$. womersleyi strain was collected from an apple orchard in Morioka $\left(39^{\circ} 42^{\prime} \mathrm{N}-141^{\circ} 11^{\prime} \mathrm{E}\right)$, Iwate Pref., in the northern part of Japan, on 1 October 1999. The mite strains were maintained on leaves of kudzu vine Pueraria lobata (Willd.) (June-October) or common bean Phaseolus vulgaris L. (November-May) that were infested with the spider mite Tetranychus urticae Koch (red form). Each leaf was placed on a moist filter paper in a plastic cup ( $80 \mathrm{~mm} \varnothing$ top $\times 55 \mathrm{~mm} \varnothing$ bottom $\times 60 \mathrm{~mm}$ high) with a perforated lid at $20 \pm 1{ }^{\circ} \mathrm{C}$ and under a $16 \mathrm{~L}: 8 \mathrm{D}$ photoperiod. The lid of each cup had a 30 $\mathrm{mm}$-diameter hole covered with fine nylon mesh to allow ventilation.

Diapause propensity. To determine whether $N$. californicus entered diapause, 60 adult females from the stock culture were transferred to fresh bean leaves with spider mites and allowed to lay eggs for $24 \mathrm{~h}$ at $15 \pm 1{ }^{\circ} \mathrm{C}$ and under a photoperiod of either $8 \mathrm{~L}: 16 \mathrm{D}$ (short-day, SD) or 16L:8D (long-day, LD). Eggs laid were singly placed and reared on a fresh leaf disc, and the developmental stages were recorded daily. Leaf discs on which the egg developed into a male were discontinued. When a female deutonymph emerged, one adult male obtained from a stock culture of the same strain was introduced onto the leaf disc for mating and then removed $48 \mathrm{~h}$ after emergence of the adult female. Following emergence, the female was observed daily for at least 26 days to record the first oviposition date. The same experiment was carried out for $N$. womersleyi, which was shown to enter diapause under an SD photoperiod (Hamamura, 1982).

Supercooling point (SCP) of two phytoseiid mites. The SCPs of adult females were compared among the individuals from the indigenous $N$. californicus strain, the Spical strain, the diapause $N$. womersleyi and the non-diapause $N$. womersleyi. We used five- to ten-day-old females that developed from eggs at $15^{\circ} \mathrm{C}$ either under LD (the non-diapause $N$. womersleyi) or SD (the two $N$. californicus strains and the diapause $N$. womersleyi). All females were mated with males of the same strain. The mites were placed individually in a test tube $(10 \mathrm{~mm} ø \times 40 \mathrm{~mm} \mathrm{H})$ in which the dorsum of each mite was in contact with the tip of a copper-constantan thermocouple connected to a recorder (Soft Thermo E830; Technol Seven, Yokohama, Japan). Mites were cooled to their supercooling point at a rate of approximately $1^{\circ} \mathrm{C} \mathrm{min}^{-1}$. The SCP was recorded as the lowest temperature reached just before the release of latent heat of fusion as the body water froze (Tanaka and Watanabe, 2003).

Cold hardiness. Four types of mites were examined: the indigenous and Spical strains of $N$. californicus and the diapause and non-diapause $N$. womersleyi. Prior to cold exposure, the two $N$. californicus strains and the diapause $N$. womersleyi were reared under SD at $15^{\circ} \mathrm{C}$, while the non-diapause $N$. womersleyi was reared under LD at $15^{\circ} \mathrm{C}$. For each of the four types of mite, fifteen 5 - to10-day-old adult females were placed in seven small plastic Beem $^{\circledR}$ capsules $(6 \varnothing$ by $15 \mathrm{~mm} \mathrm{H}$ ) with a piece of bean leaf ( 3 by $6 \mathrm{~mm}$ ), i.e., $4 \times 7=28$ capsules were prepared. Then four capsules, one for each type of mite, were placed in each of seven plastic cups with moist filter paper. The seven cups were kept at $0^{\circ} \mathrm{C}$ for 7 days under continuous darkness (DD). Then six of the cups were transferred to $\mathrm{a}-5^{\circ} \mathrm{C}$ incubator 
and removed one at a time after 1, 3, 5, 7, 10 and 12 days. The seventh cup was treated as the 0 time sample. After the cold exposure, the females were released on individual bean leaf discs with spider mites as food and kept at $20^{\circ} \mathrm{C}$ under an LD photoperiod for $24 \mathrm{~h}$. At this time, females that could walk were considered to be alive.

To determine the fecundity of females that survived exposure to $-5^{\circ} \mathrm{C}$, individual females were placed on bean leaf discs containing spider mites as food and were maintained at $20^{\circ} \mathrm{C}$ under LD. The number of eggs laid by each female within the first 10 days of oviposition was recorded. Each egg was placed on a fresh leaf disc and was observed for at least 10 days to see if it hatched.

Data analyses. One-way analysis of variance (ANOVA) was used to compare the preoviposition period, the SCPs, the number of eggs laid within the first 10 days of oviposition, and egg hatchability as well as the number of eggs laid during the first 5 days, hatchability, survival rate in immature stages and sex ratio in crossing experiment. Means were compared using the Tukey-Kramer method with JMP (SAS Institute, 2002). For analysis, values were arcsine-square root transformed. Fisher's exact probability test was used for analysis of survival rate at $-5^{\circ} \mathrm{C}$, and the type-I error was corrected with the Bonferroni method (Sokal and Rohlf, 1995).

\section{RESULTS}

\section{Diapause ability}

In the two strains of $N$. californicus reared at $15^{\circ} \mathrm{C}$ and under an SD photoperiod, $100 \%$ of the females oviposited within 6 days (Table 1). At $15^{\circ} \mathrm{C}$ and under an LD photoperiod, $100 \%$ of the females of the indigenous $N$. californicus oviposited within 6 days. There was no difference in the preoviposition periods between individuals developed under SD and under LD, indicating that these strains do not have reproductive diapause. In contrast, none of adult females of $N$. womersleyi that were reared under SD oviposited even when adult females were observed for more than 26 days (ranging from 26 to 37 days) after emergence of adult females (Table 1). When $N$. womersleyi was reared under LD, 100\% of females oviposited within 9 days (Table 1), indicating that this species had entered diapause as previously reported (Hamamura, 1982). The total developmental period of females in the indigenous $N$. californicus strain was similar to that in the Spical strain of the same species ( $p>0.05$, Tukey-Kramer method, Table 1).

\section{Supercooling points}

No significant differences were detected in the SCPs between the two strains of $N$. californicus or between the diapause and non-diapause individuals of $N$. womersleyi (Table 2). However, the indigenous $N$. californicus strain had a slightly higher SCP than the diapause $N$. womersleyi ( $p<0.05$, Tukey-Kramer method).

\section{Cold hardiness}

When the predatory mites were exposed to $-5^{\circ} \mathrm{C}$ for various periods after an acclimation period of 7 days at $0^{\circ} \mathrm{C}$, more than $50 \%$ of diapause females of $N$. womersleyi survived more than 7 days (Fig. 1). By contrast, most females of the two N. californicus strains and the non-diapause $N$. womersleyi died after 5 days of exposure to $-5^{\circ} \mathrm{C}$. 
Cold hardiness of predatory mites




Table 2. Mean supercooling points (SCPs, mean \pm S.E.) of adult females of N. californicus and N. womersleyi

\begin{tabular}{cllccc}
\hline Species & \multicolumn{1}{c}{ Strain $^{\mathrm{a}}$} & $\mathrm{N}^{\mathrm{b}}$ & $\mathrm{SCP},{ }^{\circ} \mathrm{C}$ & Range & $95 \%$ fiducial limits \\
\hline \multirow{2}{*}{ N. californicus } & Indigenous (SD) & 36 & $-21.9 \pm 0.29 \mathrm{~b}$ & $-16.5 \sim-24.1$ & $-21.4 \sim-22.5$ \\
& Spical (SD) & 37 & $-22.2 \pm 0.29 \mathrm{ab}$ & $-17.5 \sim-26.0$ & $-21.6 \sim-22.8$ \\
N. womersleyi & Non-diapause (LD) & 36 & $-22.9 \pm 0.23 \mathrm{ab}$ & $-20.7 \sim-27.4$ & $-22.5 \sim-23.4$ \\
& Diapause (SD) & 37 & $-23.3 \pm 0.39 \mathrm{a}$ & $-17.7 \sim-31.4$ & $-22.5 \sim-24.1$ \\
$F^{\mathrm{c}}$ & & & 4.335 & & \\
$\mathrm{df}$ & & 3,142 & \\
$p$ & & 0.006 & \\
\hline
\end{tabular}

${ }^{\mathrm{a}} \mathrm{SD}$ means that individuals developed at $15^{\circ} \mathrm{C}$ and under a $8 \mathrm{~L}: 16 \mathrm{D}$ photoperiod; LD means that individulas developed at $15^{\circ} \mathrm{C}$ and under a $16 \mathrm{~L}: 8 \mathrm{D}$ photoperiod.

${ }^{\mathrm{b}}$ Number of adult females tested.

${ }^{\mathrm{c}}$ Data were analysed using ANOVA. Values within columns followed by the same letter were not significantly different at the $5 \%$ level (Tukey-Kramer method).

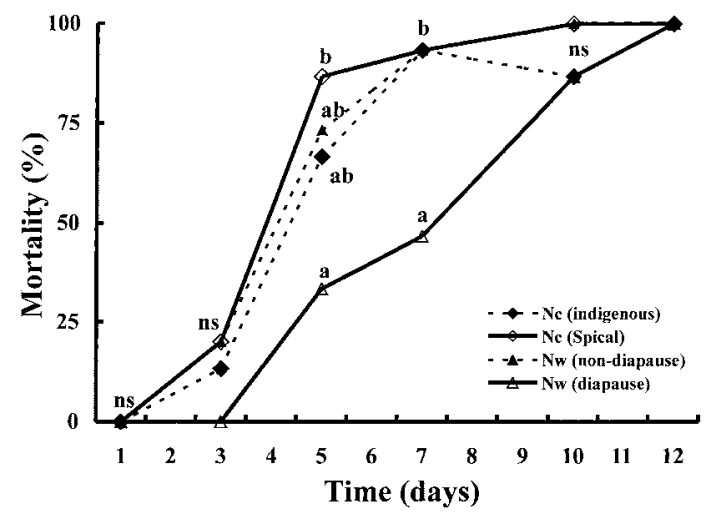

Fig. 1. Mortality of adult females of $N$. californicus $(\mathrm{Nc})$ and $N$. womersleyi $(\mathrm{Nw})$, after being reared at $15^{\circ} \mathrm{C}$ and exposed to $-5^{\circ} \mathrm{C}$ for various periods of time. The non-diapause $N$. womersleyi was developed under a $16 \mathrm{~L}: 8 \mathrm{D}$ photoperiod, and the other three strains were developed under a $8 \mathrm{~L}: 16 \mathrm{D}$ photoperiod. Before exposure to $-5^{\circ} \mathrm{C}$, females were acclimated for 7 days at $0^{\circ} \mathrm{C}$ and under continuous darkness. Values followed by the same letter were not significantly different at the 5\% level (Fisher's exact probability test with the Bonferroni method). ns, not significantly different at the $5 \%$ level. Numbers of individuals tested were 15 adult females for each strain.

As shown in Fig. 2, a significant reduction in fecundity occurred in females that survived exposure to $-5^{\circ} \mathrm{C}$ for various periods in the two phytoseiid species: $\mathrm{F}_{5,45}=4.745(p=0.0014)$ for the indigenous $N$. californicus strain, $\mathrm{F}_{4,40}=40.837(p<0.0001)$ for the Spical strain, $\mathrm{F}_{4,42}$ $=9.335(p<0.0001)$ for the non-diapause $N$. womersleyi, and $\mathrm{F}_{5,59}=28.555(p<0.0001)$ for the diapause $N$. womersleyi. All but two of the surviving females that were exposed to $-5^{\circ} \mathrm{C}$ for various periods laid eggs within 10 days at $20^{\circ} \mathrm{C}$. The two that did not lay eggs were one female of the Spical strain that survived when exposed to $-5^{\circ} \mathrm{C}$ for 7 days, and one of two surviving females of the diapause $N$. womersleyi that were exposed to $-5^{\circ} \mathrm{C}$ for 10 days. 


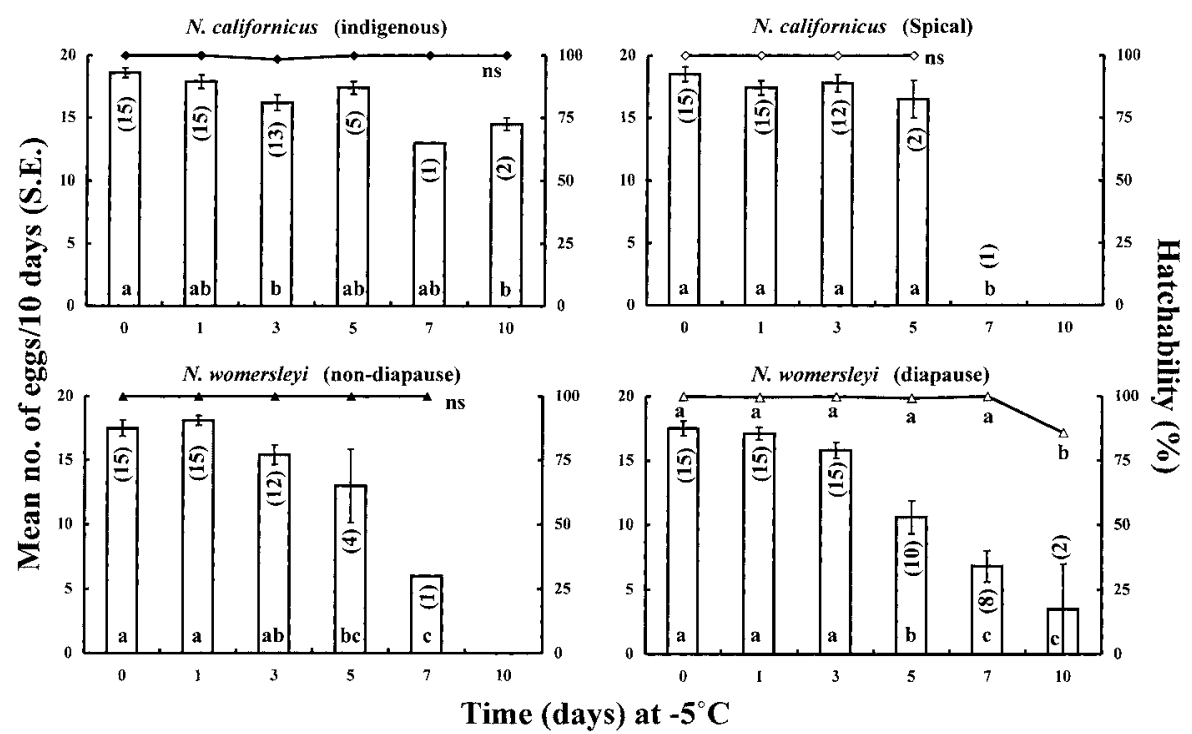

Fig. 2. Mean number of eggs ( \pm S.E.) laid within 10 days (bars) and their hatchability (lines) at $20^{\circ} \mathrm{C}$ and under a $16 \mathrm{~L}: 8 \mathrm{D}$ photoperiod by females of $N$. californicus and $N$. womersleyi after exposure to $-5^{\circ} \mathrm{C}$ for various periods of time. Before exposure to $-5^{\circ} \mathrm{C}$, females were acclimated for 7 days at $0^{\circ} \mathrm{C}$ and under continuous darkness. Numbers in parentheses indicate the number of females that survived. Values followed by the same letter were not significantly different at the $5 \%$ level (TukeyKramer method). ns, not significantly different at the $5 \%$ level.

The number of eggs laid was not significantly different among the four strains except when females were exposed to $-5^{\circ} \mathrm{C}$ for 5 days $\left(\mathrm{F}_{3,17}=3.466, p=0.0395\right)$. In this case, the diapause $N$. womersleyi laid fewer eggs than the indigenous $N$. californicus strain $(p<0.05$, Tukey-Kramer method).

Most eggs laid by females that survived exposure to $-5^{\circ} \mathrm{C}$ were viable and hatched within 5 days at $20^{\circ} \mathrm{C}$. Among the different strains, only the diapause $N$. womersleyi $(\mathrm{n}=1)$ that was exposed to $-5^{\circ} \mathrm{C}$ for 10 days showed a significantly reduced hatchability $(p<0.05$, TukeyKramer method). Six out of seven eggs laid by this female hatched (85.7\%) (Fig. 2).

\section{DISCUSSION}

The present study shows that the indigenous and alien (Spical) strains of the predatory mite $N$. californicus did not enter diapause even under SD conditions. Almost all individuals $(84-100 \%)$ of the Italian and the UK strains of $N$. californicus underwent diapause (Castagnoli et al., 1996; Jolly, 2000), while neither of two USA strains entered diapause (Hart et al., 2002; Jolly, 2000). Thus, diapause ability of $N$. californicus varies among strains; i.e., some strains have a genetic propensity for diapause, suggesting that this propensity can be easily introduced into non-diapause individuals or can be easily eliminated from diapause individuals by cross breeding, because the Japanese (indigenous) strain and the Spical strain that is imported from the Netherlands are not reproductively incompatible 
Table 3. Supercooling points (SCPs) in adult females of phytoseiid mites

\begin{tabular}{|c|c|c|c|c|}
\hline Species (strain) & Development condition $^{\mathrm{a}}$ & $\mathrm{SCP},{ }^{\circ} \mathrm{C}$ & Difference $^{b}$ & Reference \\
\hline \multirow[t]{2}{*}{ Amblyseius cucumeris } & ND & -20.7 & \multirow{2}{*}{ ns } & \multirow[t]{2}{*}{ Morewood, 1992} \\
\hline & $\mathrm{D}$ & -21.6 & & \\
\hline \multirow[t]{3}{*}{ Euseius finlandicus } & ND & $-22.8 \sim-23.7$ & \multirow{3}{*}{ ns } & \multirow[t]{2}{*}{ Broufas \& Koveos, 2001a } \\
\hline & $\mathrm{D}$ & $-23.0 \sim-23.1$ & & \\
\hline & Field & -30.2 & & MacPhee, 1963 \\
\hline Phytoseiulus persimilis & SD & -22.5 & & Morewood, 1992 \\
\hline Typhlodromips montdorensis & LD & $-22.4 \sim-24.1$ & & Hatherly et al., 2004 \\
\hline \multirow[t]{2}{*}{ Typhlodromus pyri } & Field & $-17.0 \sim-28.9$ & & Moreau et al., 2000 \\
\hline & Field & -29.1 & & MacPhee, 1963 \\
\hline Typhlodromus rhenanus & Field & -31.4 & & MacPhee, 1963 \\
\hline \multirow[t]{2}{*}{ Neoseiulus californicus } & $\mathrm{LD}$ & -21.6 & \multirow[b]{2}{*}{$\mathrm{ns}$} & \multirow[t]{2}{*}{ Hart et al., 2002} \\
\hline & SD & -22.2 & & \\
\hline (indigenous) & SD & -21.9 & \multirow{2}{*}{$\mathrm{ns}$} & \multirow[t]{2}{*}{ Present study } \\
\hline$\left(\right.$ Spical $\left.^{\circledR}\right)$ & SD & -22.2 & & \\
\hline \multirow[t]{2}{*}{ Neoseiulus womersleyi } & ND & -22.9 & \multirow[b]{2}{*}{$\mathrm{ns}$} & \multirow[t]{2}{*}{ Present study } \\
\hline & $\mathrm{D}$ & -23.3 & & \\
\hline
\end{tabular}

${ }^{a}$ Adult females developed under diapause-averting condition (ND), diapause-inducing condition (D), short-day photopeiod (SD), long-day photoperiod (LD) and field conditions (Field).

${ }^{\mathrm{b}} \mathrm{ns}$, not significantly different at the $5 \%$ level.

(Appendix 1). The ability to enter diapause may be necessary to sustain biocontrol agents in orchards.

The mean SCPs $\left(-21.9 \sim-23.3^{\circ} \mathrm{C}\right.$ for adult females) of $N$. californicus and $N$. womersleyi obtained in this study were comparable to those of other predatory mites (Table 3). For example, the SCPs of a USA strain of $N$. californicus developed under long-day and shortday photoperiods were -21.6 and $-22.2^{\circ} \mathrm{C}$, respectively, and the difference was not significant (Hart et al., 2002). The SCP of Phytoseiulus persimilis, which has no diapause ability, was $-22.5^{\circ} \mathrm{C}$ when developed under a short-day photoperiod (Morewood, 1992). On the other hand, in species having diapause ability, the SCPs were not significantly different between diapause and non-diapause individuals (Broufas and Koveos, 2001a; Morewood, 1992; Tables 2 and 3). In most mites and insects with tiny body sizes, the SCPs range from -15 to $-30^{\circ} \mathrm{C}$ (Lee, 1991; Sømme, 1982) even in the species that have a diapause ability. The mean SCPs obtained from phytoseiid mites were similar to each other and were around $-20^{\circ} \mathrm{C}$ with a slight variation (Table 3 ). These data suggest that the SCPs may be an inherent characteristic of the mite due to its small size rather than a physiological adaptation to environmental severity (Broufas and Koveos, 2001a). This is because small volumes of water remain in the liquid state below the melting point (i.e., they have a remarkable ability to supercool). For example, $5 \mu \mathrm{l}$ samples of tap water supercool to $-18^{\circ} \mathrm{C}$ or lower before ice forms spontaneously (Lee, 1991). This might explain why the SCPs of diapause females were not significantly different from those of non-diapause females. If this explanation is correct, the SCPs might not be useful as an indicator of cold hardiness of mites.

Cold hardiness of Euseius finlandicus was conspicuously different between diapause and 
non-diapause females: most diapause females survived exposure to $-4^{\circ} \mathrm{C}$ for 11 days, while most non-diapause females died after 1-2 days of exposure to $-4^{\circ} \mathrm{C}$ (Broufas and Koveos, 2001a). The present data show that diapause females of $N$. womersleyi survived exposure to $-5^{\circ} \mathrm{C}$ slightly longer (7-10 days) than did non-diapause females of $N$. womersleyi (3-5 days) and females of the two $N$. californicus strains (3-5 days). The northernmost site in Japan that $N$. womersleyi has been recorded is Sapporo $\left(43^{\circ} \mathrm{N}\right)$ (Kishi and Mori, 1979). During the years 1995-2005, the mean monthly temperatures for January in Sapporo ranged from -5.9 to $-2.5^{\circ} \mathrm{C}$. During January, temperatures rise above $0^{\circ} \mathrm{C}$ only a few days of month. Under such field conditions, $N$. womersleyi could overwinter successfully. On the other hand, the northernmost site at which $N$. californicus has been recorded is Fukushima $\left(37-38^{\circ} \mathrm{N}\right)$ (Amano, unpublished data), where the mean January temperatures during the years 19952005 ranged from -0.1 to $3.5^{\circ} \mathrm{C}$. Furthermore, non-diapause females of a USA strain of $N$. californicus survived over three months outdoors in winter under sheltered condition in UK, where the temperature did not fall below $0^{\circ} \mathrm{C}$ (Hart et al., 2002). Consequently, the lower cold tolerance of $N$. californicus might be one of the factors halting its northern advance, but it is probably not sufficient to be the only factor. This is because the present study shows that exposure of adult females to $-5^{\circ} \mathrm{C}$ for various periods had little effect on subsequent fecundity and egg viability for those females that survived. Further experiments are needed to clarify the difference of cold tolerance between $N$. californicus and $N$. womersleyi. Additional parameters that needed to be measured include survival at temperatures less than $-5^{\circ} \mathrm{C}$, the lethal time for $50 \%$ mortality at various subzero temperatures, and actual mortality in the field.

\section{ACKNOWLEDGEMENTS}

We thank H. Amano for providing the indigenous strain of $N$. californicus, J. Kamata for providing the Spical strain of this species, and S. Toyoshima for providing N. womersleyi.

\section{REFERENCES}

Amano, H., Y. Ishii and Y. Kobori (2004) Pesticide susceptibility of two dominant phytoseiid mites, Neoseiulus californicus and N. womersleyi, in conventional Japanese fruit orchards (Gamasina: Phytoseiidae). Journal of the Acarological Society of Japan, 13: 65-70.

Broufas, G. D. and D. S. Koveos (2001a) Cold hardiness characteristics in a strain of the predatory mite Euseius (Amblyseius) finlandicus (Acari: Phytoseiidae) from northern Greece. Annals of Entomological Society of America, 94: 82-90.

Broufas, G. D. and D. S. Koveos (2001b) Rapid cold hardening in the predatory mite Euseius (Amblyseius) finlandicus (Acari: Phytoseiidae). Journal of Insect Physiology, 47: 699-708.

Castagnoli, M., M. Liguori, S. Simoni, M. Pintucci, S. Guidi and L. Falchini (1996) Observations on diapause induction in three phytoseiid (Phytoseiidae) species. In: Acarology IX. Vol. 1. (eds., Michell, R., D. J. Horn, G. R. Needham and W. C. Welbourn), pp. 425-431, The Ohio Biological Survey, Columbus.

Castagnoli, M., S. Simoni and N. Biliotti (1999) Mass-rearing of Amblyseius californicus (McGregor) (Acari: Phytoseiidae) on two alternative food sources. In: Ecology and Evolution of the Acari. (eds., Bruin, J., L. P. S. van der Geest and M. W. Sabelis), pp. 425-431, Kluwer Academic Publishers, Dordrecht.

Ehara, S. (1964) Some mites of the families Phytoseiidae and Blattisocidae from Japan (Acarina: Mesostigmata). 
The Journal of the Faculty of Science, Hokkaido University, Series 6, Zoology, 15: 378-394.

Ehara, S., Y. Okada and H. Kato (1994) Contribution to the knowledge of the mite family Phytoseiidae in Japan (Acari: Gamasida). The Journal of the Faculty of Education, Tottori University (Natural Science), 42: 119-160.

Gotoh, T., K. Yamaguchi and K. Mori (2004) Effect of temperature on life history of the predatory mite Amblyseius (Neoseiulus) californicus (Acari: Phytoseiidae). Experimental and Applied Acarology, 32: 15-30.

Hamamura, T. (1982) Studies on the diapause of the predacious mite, Amblyseius longispinosus (Evans) (Acarina: Phytoseiidae). Bulletin of Fruit Tree Research Station, E4: 77-89. (in Japanese with an English summary)

Hart, A. J., J. S. Bale, A. G. Tullett, M. R. Worland and K. F. A. Walters (2002) Effects of temperature on the establishment potential of the predatory mite Amblyseius californicus McGregor (Acari: Phytoseiidae) in the UK. Journal of Insect Physiology, 48: 593-599.

Hatherly, I. S., J. S. Bale, K. F. A. Walters and M. R. Worland (2004) Thermal biology of Typhlodromips montdorensis: implications for its introduction as a glasshouse biological control agent in the UK. Entomologia Experimentalis et Applicata, 111: 97-109.

Jolly, R. L. (2000) The predatory mite Neoseiulus californicus: its potential as a biocontrol agent for the fruit tree red spider mite Panonychus ulmi in the UK. Proceedings of the 2000 Brighton Conference-Pests and Diseases, 1: $487-490$.

Kishi, N. and H. Mori (1979) The seasonal fluctuations of four species of phytoseiid mites in Sapporo, Hokkaido (Acarina: Phytoseiidae). Memoirs of Faculty of Agriculture, Hokkaido University, 11: 245-257. (in Japanese with an English summary)

Kishimoto, H. and A. Takafuji (1994) Variations in the diapause characteristics of Amblyseius womersleyi Schicha (Acari: Phytoseiidae). Journal of the Acarological Society of Japan, 3: 59-67.

Lee, R. E. Jr. and D. L. Denlinger (1985) Cold tolerance in diapausing and non-diapausing stages of the flesh fly, Sarcophaga crassipalpis. Physiological Entomology, 10: 309-315.

Lee, R. E. Jr. (1991) Principles of insect low temperature tolerance. In: Insects at Low Temperature (eds., Lee, R. E. Jr. and D. L. Denlinger), pp. 17-46, Chapman and Hall, New York.

MacPhee, A. W. (1963) The effect of low temperatures on some predacious phytoseiid mites, and on the brown mite Bryobia arborea M. \& A. Canadian Entomologist, 95: 41-44.

Moreau, D. L., J. M. Hardman and O. Kukal (2000) Supercooling capacity and survival of low temperatures by a pyrethroid-resistant strain of Typhlodromus pyri (Acari: Phytoseiidae). Environmental Entomology, 29: 683-689.

Morewood, W. D. (1992) Cold hardiness of Phytoseiulus persimilis Athias-Henriot and Amblyseius cucumeris (Oudemans) (Acarina: Phytoseiidae). Canadian Entomologist, 124: 1015-1025.

Sabelis, M. W. (1985) Development. In: Spider Mites. Their Biology, Natural Enemies and Control. B (eds., Helle, W. and M. W. Sabelis), pp. 43-53, Elsevier, Amsterdam.

Salt, R. W. (1961) Principles of insect cold hardiness. Annual Review of Entomology, 6: 55-74.

SAS Institute (2002) JMP ${ }^{\circledR}$ Guide, Ver. 5. 167p., SAS Institute Inc., Cary. (in Japanese)

Schausberger, P. and B. A. Croft (2000) Nutritional benefits of intraguild predation and cannibalism among generalist and specialist phytoseiid mites. Ecological Entomology, 25: 473-478.

Sokal, R. R. and F. J. Rohlf (1995) Biometry, 3rd ed., 887 p., W. H. Freeman \& Co., New York.

Sømme, L. (1982) Supercooling and winter survival in terrestrial arthropods. Comparative Biochemistry and Physiology, 73A: 519-543.

Tanaka, K. and M. Watanabe (2003) Transmission of ice-nucleating active bacteria from a prey reduces cold hardiness of a predator (Araneae: Theridiidae). Naturwissenschaften, 90: 449-451.

\section{摘要}

ミヤコカブリダニとケナガカブリダニの耐寒性

後藤 哲雄・䅖澤 崇・渡邊 匡彦 1 土屋 明子・嶋崎 明香（茨城大学農学部・1 生物資源研） ミヤコカブリダニ（ミヤコ）の個体数は, 1990 年以降に日本各地で急激に増加し, 関東以 西の慣行防除果樹園ではそれまでの優占種であったケナガカブリダニ(ケナガ)と置き換わっ 
てきている. 一方, 北日本への分布の拡大傾向は小さい。 このような種の置換と分布拡大の 要因を明らかにする一環として, 本報告ではミヤコの休眠性の有無と 2 種の耐寒性を報告す る.

ミヤコは，短日条件と長日条件の産卵前期間が同じであり，休眠性はなかった. 2 種間お よびケナガの休眠と非休眠個体間の過冷却点（supercooling point）に有意差はなく，-21.9〜 $-23.3^{\circ} \mathrm{C}$ であった．ケナガ・休眠雌は， $-5^{\circ} \mathrm{C}$ で 7 日以上生存した（ $\left.>50 \%\right)$ が，ミヤコとケナ ガ・非休眠雌は 5 日以内に $70 \sim 85 \%$ 歹亡した. このことからミヤコの北進が遅いのは耐 寒性がわずかに弱いことも一因であると考兄られた。一方，いずれの種においても生残した 雌は $20^{\circ} \mathrm{C}$ 長日条件下で 2 個体を除いて産卵し, 産下卵の大半がふ化した. 従って, 低温ス トレスは産卵数やふ化率への影響が少なく，ミヤコも冬季の低温条件下で生き残ることがで きる地域では，定着が可能であると考えられた。

Appendix 1. Hatchability of eggs laid during the first 5 days of the oviposition period, survival rate of immature stages and the proportion of females reaching adulthood in crosses between the indigenous (I) and the Spical (S) strains of $N$. californicus at $25^{\circ} \mathrm{C}$ and under a $16 \mathrm{~L}: 8 \mathrm{D}$ photoperiod. Predatory mites fed on spider mites (all stages) infesting common bean.

\begin{tabular}{cccccc}
\hline Female $\times$ Male & $\mathrm{N}^{\mathrm{a}}$ & $\begin{array}{c}\text { No. of } \\
\text { eggs/female }\end{array}$ & $\begin{array}{c}\text { Hatchability } \\
(\%)\end{array}$ & $\begin{array}{c}\text { Survival rate in } \\
\text { immatures }(\%)\end{array}$ & $\begin{array}{c}\text { Proportion of } \\
\text { females }(\%)\end{array}$ \\
\hline $\mathrm{I} \times \mathrm{I}$ & 14 & $13.5 \pm 0.71 \mathrm{a}$ & $98.5 \pm 0.79 \mathrm{a}$ & $97.0 \pm 1.21 \mathrm{~b}$ & $69.5 \pm 1.46 \mathrm{ab}$ \\
$\mathrm{S} \times \mathrm{S}$ & 15 & $18.1 \pm 0.42 \mathrm{c}$ & $98.7 \pm 0.99 \mathrm{a}$ & $97.6 \pm 0.81 \mathrm{~b}$ & $73.1 \pm 1.29 \mathrm{~b}$ \\
$\mathrm{I} \times \mathrm{S}$ & 18 & $14.1 \pm 0.45 \mathrm{ab}$ & $94.3 \pm 1.66 \mathrm{a}$ & $91.1 \pm 1.68 \mathrm{a}$ & $65.4 \pm 2.18 \mathrm{a}$ \\
$\mathrm{S} \times \mathrm{I}$ & 15 & $15.9 \pm 0.54 \mathrm{bc}$ & $97.6 \pm 0.79 \mathrm{a}$ & $91.3 \pm 2.18 \mathrm{ab}$ & $63.3 \pm 1.80 \mathrm{a}$ \\
$F^{\mathrm{b}}$ & & 13.239 & 2.755 & 4.265 & 5.747 \\
$\mathrm{df}$ & & 3,58 & 3,58 & 3,58 & 3,58 \\
$p$ & & $<0.0001$ & 0.050 & 0.009 & 0.002 \\
\hline
\end{tabular}

\footnotetext{
${ }^{\text {a }}$ Number of females tested. Data are shown as mean \pm S.E.

${ }^{\mathrm{b}}$ Data were analysed using ANOVA. Values within columns followed by the same letter were not significantly different at the $5 \%$ level (Tukey-Kramer method).
} 